\title{
CRUZANDO LÍMITES: CUESTIONES CRÍTICAS Y FORMAS ACTUALES DE LA NARRATIVA ESCRITA POR MUJERES
}

\author{
Teresa Orecchia Havas \\ Université de Caen-Basse Normandie
}

\section{Del LAdo de LA TEORÍA}

El conjunto de los trabajos dedicados a la escritura de mujeres desde los inicios del último cuarto del siglo $x x$, permite sin duda hacer un balance de las principales etapas superadas en el proceso de reconocimiento crítico de las obras y de sus autoras, pero no alcanza a disipar la sensación de que la cuestión del género (gender) en relación con la creación literaria sigue remitiendo a un estadio teórico que no está estabilizado. Sobre todo, y pesar del esfuerzo epistemológico de las últimas décadas, esa cuestión, desplegada en un periodo de fuertes luchas simbólicas y sociales, no parece haber alcanzado la riqueza de hipótesis que la confrontación de la teoría con los discursos puntuales de la creación hubiera dejado lógicamente esperar, tanto en el marco de la producción metropolitana (de los Estados Unidos, pero también europea y en este caso, en especial la francesa) como en el contexto de los aportes teóricos de los países de habla hispana ${ }^{1}$.

\footnotetext{
${ }^{1}$ Aun cuando el afinamiento de las pistas de abordaje de las obras haya logrado desplazar a partir de los años ochenta las lecturas convencionales sobre la producción femenina, que eran habituales hasta principios de los setenta tanto en la academia como fuera de ella, no son tan numerosas las hipótesis de trabajo crítico que han representado auténticas cuñas epistemológicas. Entre ellas, sin embargo, y dejando aparte los estudios de orden histórico-social, los estrictamente temáticos y los que se aplican a materiales como diarios íntimos, correspondencia, etc., en los que hay ejemplos notorios de excelencia, quisiera mencionar como especialmente rigurosas y estimulantes en el
} 
Centrando su reflexión en el decaimiento del interés actual de las teorías feministas por el problema de las estéticas y de la creatividad femeninas, Toril Moi (2009) propone un recorrido histórico por las razones teoréticas que han llevado al relativo abandono del asunto. La década en que se consagra la fertilidad científica de esa problemática es en efecto la que va desde la mitad de los setenta a la mitad de los ochenta, cuando todo lo relacionado con la producción artística de las mujeres se confirmaba como un área de amplio alcance exegético ${ }^{2}$ y los debates sobre el concepto de écriture féminine alcanzaban su punto más alto. Ese momento coincidía, por otra parte, con un flujo abundante de obras escritas por mujeres -esto es especialmente cierto en el área latinoamericana-. En cambio, tanto el post-estructuralismo (específicamente Derrida y Foucault) con su radical puesta en cuestión del autor, del sujeto y del humanismo liberal, como la inclinación de algunas feministas en favor de la acción y la práctica política, como por fin la enorme influencia de las posiciones de Judith Butler-Gender Trouble (1990), Bodies That Matter (1993)-, quien parte de una bienvenida posición antiesencialista, pero cuyo objeto principal no es la literatura, llevaron a las vanguardias de la teoría feminista a dejar de lado la especulación sobre la relación entre el sexo o el género de un autor y la dinámica de la escritura literaria. Sin embargo, es evidente que muchos críticos de valor trabajan hoy sobre obras escritas por mujeres, dentro y fuera del ámbito académico, iluminando zonas enteras del pasado y acompañando la producción de las nuevas generaciones de autoras, y que los interrogantes planteados en las tres décadas pasadas siguen en gran parte abiertos. Toril Moi aboga en su conclusión por un retorno a la investigación teorética sobre la creación femenina a partir del sujeto femenino, y a la búsqueda de respuesta a preguntas aparentemente tan simples como la de por qué y desde qué posición subjetiva escriben las mujeres, o la de cómo entender la importancia del sexo o del género del artista en relación con la obra. En cuanto al estado de la teoría, ella concluye:

Today, then, theory and practice appear to be just as out of synch as they were by the end of the 1980s. The result is a kind of intellectual schizophrenia, in which one half of the brain continues to read women writers while the others continue to think that the author is dead, and the very word "woman" is theoretically dodgy. No wonder, then, that so many books and essays on women writers begin with a series of apologies. [...] Such formulations are symptoms of

ámbito hispánico las tesis sobre la voz y las heteroglosias, que analizan el lugar de enunciación en los textos escritos por mujeres. Se basan en modelos sociolingüísticos (Bakhtine), entrecruzados a veces con referencias psicoanalíticas. Estos modelos han dado algunos trabajos notables en los últimos quince años, en especial en el campo de la poesía, por ejemplo en torno a la cuestión de la doble voz, de las voces travestidas y de las estéticas paródicas. Pienso en los libros de Susana Reisz (1996) y de Alicia Genovese (1998), por ejemplo. También hay que mencionar los ensayos sobre las representaciones autoficcionales o sobre la autofiguración, porque alcanzan un valor analítico que intenta superar la relación a un solo objeto, además de ser particularmente oportunos en literaturas como la hispanoamericana, donde la tradición de la autorrepresentación y de la autobiografía se ve reforzada con una serie de obras recientes escritas por mujeres.

2 Una prueba indirecta pero no menos contundente de esta situación se puede obtener echando un vistazo al volumen de intervenciones críticas sobre la obra de Julia Kristeva producidas en la década de los ochenta y principios de los noventa. 
a theoretical malaise. [...] This is one of the rare situations today in which I would argue that there actually is a need for more theory (or more philosophy, if you prefer). We actually need to be able to justify theoretically a kind of work that many women and men clearly think is important, and that has no problem at all justifying itself politically. (Moi 2009)

Creo que esta perspectiva expone lúcidamente el marco epistemológico en el que nos movemos hoy. Comenzaré entonces recordando, en el mismo sentido, que toda reflexión sobre este campo en el ámbito de las literaturas latinoamericanas debería partir de la idea de que diversas zonas de debate disciplinario están todavía (felizmente) abiertas. Y que esto es así aun cuando los últimos veinticinco años han representado un esfuerzo sin precedentes de revaloración y ajuste analítico sobre la escritura femenina, y aunque muchos aportes hayan venido a enriquecer esa problemática, tanto desde el corpus de obras recientes escritas por mujeres, como desde la ensayística dedicada a ellas, e incluso desde las instituciones (fundación de los departamentos de estudios de género en las principales universidades, publicaciones especializadas avaladas por la academia). Tomo aquí por testigo a notorias especialistas, como Sylvia Molloy o Sara Castro Klarén, quien en su ensayo introductorio al volumen Narrativa Femenina en América Latina, después de hacer un balance de los aportes del feminismo post-estructuralista y de evocar sus impasses teoréticos, así como la relación compleja que mantienen con la teoría los nuevos lenguajes narrativos, concluye su informe subrayando la necesidad de volver a la experiencia histórica de los sujetos femeninos y remitiendo a los textos mismos, como si en definitiva, la panoplia de posiciones subjetivas diferentes, la variedad de construcciones imaginarias, el estallido de modos de saber, de sentir y de narrar característicos de un largo fin de siglo hubieran ingresado con tal abundancia al patrimonio de la creación escrita que el panorama volviera imposibles las aproximaciones unívocas. Dice Castro-Klarén:

The coincidence of a deconstructive and disordering engagement with received narrative forms, with language itself, and the writing of the specificity of the conditions of the women who write "her" self, appears as the strongest constant [in the essays]. There emerges a rising tide that enables critics to theorize on women's writing from the very texts at hand. It is the text's work of disordering, creation of alternate voices, disobedience and transgressions, silences and testimonial strategies that flex, questions, contest and even break metropolitan theory, feminist or otherwise. (Castro Klarén 2003b: 33)

Evidentemente, el sentimiento de relativa perplejidad que suscita este abandono confeso de cierta ortodoxia metodológica (o al menos conceptual) en favor de una crítica atenta a las "voces del texto" se acentúa cuando a las contradicciones o los impasses de la discusión sobre género y escritura se agregan otros marcos de referencia, por ejemplo los parámetros dentro de los cuales se intenta pensar el fenómeno de la globalización. En este terreno, está claro que junto a la visión más o menos eufórica de los que buscan describir un nuevo orden mundial de las letras, o más ceñidamente "nuevos hispanismos interdisci- 
plinarios y transatlánticos" (Ortega 2010), o incluso una escritura indisociable del flujo de lo real, que es performance más que discurso o estilo, una escritura de la ficción-realidad (Ludmer 2010), es imposible no tomar en cuenta la dificultad de definir criterios más o menos estrictos para lo transnacional ${ }^{3}$, o pretender obviar el debate sobre el papel (función y lugar) que hay que atribuir a las tradiciones locales o regionales, o incluso a la polémica acción de academias, editoriales e instituciones españolas con respecto a las obras de los latinoamericanos (Ludmer 2010) ${ }^{4}$. Ocurre bastante a menudo que ante estas dificultades los especialistas tiendan a refugiarse actualmente en una (académicamente) recomendada aproximación comparatista, o en un aggiornamento de la noción de cosmopolitismo ${ }^{5}$, por otra parte muy pertinente y ampliamente explorada en lo que se refiere a la historia cultural de las principales naciones latinoamericanas, pero que sería sin duda necesario someter a reformulación si se la quiere aplicar de modo riguroso a la producción de las últimas décadas ${ }^{6}$.

A pesar de todas las dificultades, hoy es indudablemente necesario seguir pensando la escritura de mujeres y hacerlo asumiendo nuestro tiempo, es decir, con plena conciencia tanto de los vacíos teóricos de los sistemas hermenéuticos como de sus logros puntuales, pero sin dejar de tener en cuenta las nuevas coordenadas culturales que producen la mundialización de las comunicaciones, la conciencia de la aceleración del cambio, el contacto con las nuevas tecnologías y la dispersión de la experiencia social. Por lo cual, y si bien no es mi intención entrar ahora en otros puntos de un amplio debate del que he insinuado los estadios críticos que me parecen ineludibles, creo oportuno colocar toda consideración ulterior bajo el prudente propósito de Sylvia Molloy cuando nos previene:

No es mi intención plantear aquí una representación esencialista de la diferencia femenina -en la cual no creo demasiado- ni proponer que el deseo de ocupar un espacio diferente donde ser, y desde donde escribir, sea particular a la escritura de mujeres latinoamericanas. Más bien quiero pensar qué formas toma ese deseo (común a todas las mujeres) en un contexto específicamente

\footnotetext{
3 Por ejemplo, ¿qué significa concretamente la idea de que las generaciones o el feminismo constituyen "circuitos de identificación transnacional", como afirma Ricardo Gutiérrez Mouat (2010: 106)?

4 Una síntesis clara de algunos aspectos de esta problemática en relación con la constitución de un objeto "literatura americana o latinoamericana" puede leerse en el trabajo de María Teresa Gramuglio sobre "Los deseos renovados del americanismo", donde esta investigadora insiste en el desafío que supone pensar la literatura "con criterios que tengan en cuenta las múltiples interrelaciones que traspasan las perspectivas estrictamente nacionales", y hace hincapié en la imposibilidad de aplicar ciertos conceptos funcionales como el de campo literario (Bourdieu) sin tener en cuenta la vigencia de los Estados-nación y la consiguiente interrelación entre el campo intelectual y el campo de poder (Gramuglio 2012: 59 y 61).

${ }^{5}$ Es lo que intenta Ricardo Gutiérrez Mouat (2010).

${ }^{6}$ En caso de enmarcar el comparatismo con rigor metódico, se impondría al menos distinguir entre sus dos variantes, la que confronta textos producidos dentro de una misma área lingüística, hoy de habitual uso académico, y la de cuño filológico y universalista, que toma en cuenta textualidades en diferentes lenguas, cuya más sólida tradición científica se origina en los estudios sobre las literaturas clásicas. Recordemos al pasar que solo esta segunda forma le parecía legítima a George Steiner (1997) en tanto disciplina, es decir, suficientemente científica.
} 
latinoamericano e intentar ver cómo se inscriben esa dislocación y esa diferencia en estos textos, desafiando estereotipos culturales precisos. (Molloy 2006a: 68-69)

\section{El PROBLEMA DEL VALOR}

El trabajo analítico realizado con los textos habla, en efecto, de un salto considerable en la legitimación de la creación de mujeres en los últimos treinta años. Pero sin perder de vista este supuesto, quisiera también retener y destacar aquí dos variables que son escasamente abordadas por los investigadores con una mirada metódica -y aún menos, teórica-, pero que parecen atravesar la historia de la creación femenina, y que siguen estando vigentes, tanto en las estrategias de selección editoriales y del público lector como en la mirada analítica que suele ejercer la escritura sobre sí misma. Me refiero a la doble cuestión de la autoridad (o de la falta de autoridad) de la voz femenina y del valor (o de la falta de valor) de la literatura escrita por mujeres, asuntos que siguen determinando -aunque a veces de manera impalpable- el juicio crítico, y que, detectables en las diversas formas de la recepción literaria, son reveladores de tensiones solapadas, de núcleos resistentes de prejuicio social. Es notorio que el prestigio y la consagración académica van de par; en cambio el desafío que plantean lo inusual y lo que se percibe como (demasiado) genéricamente marcado no siempre produce exégesis independientes de los deseos canónicos. Algunos trabajos vienen oportunamente a recordárnoslo y dan testimonio de la lucha contra la desconfianza por la posible falta de "valor" de la literatura escrita por mujeres. Susana Reisz ${ }^{7}$, por ejemplo, insiste en las asignaturas pendientes en el plano de la valoración de los textos, si bien su mirada es optimista en cuanto al futuro de una crítica irrigada y revigorizada por los intercambios transdisciplinarios. Su cruzada ensayística pone en evidencia, justamente, que la infravaloración de la creación femenina suele tomar formas disimuladas pero persistentes, en el interior de las cuales siguen operando criterios patriarcales, como la reducción de la imagen de la mujer (y por lo tanto de los productos de su capacidad creadora) a su cuerpo y a su sexualidad, o la identificación de lo femenino con lo íntimo. Podríamos agregar que esto último tiene a veces resultados bastante paradójicos, como la moda crítica (en principio esclarecida y progresista) de los trabajos sobre el cuerpo y sobre las "escrituras del cuerpo" supuestamente identificables en muchas obras de autoras contemporáneas. Cito a Reisz:

De otro lado, en la banda opuesta a la de los best sellers, conviene tener presente que las escritoras oficialmente más ensalzadas suelen ser aquellas en las que la diferencia genérica resulta menos notoria y/o las que expresan a través de las oscuridades de un lenguaje artístico complejo y de difícil acceso, más acorde con la sublimidad de la gran literatura, ese territorio en el que siempre han brillado los hombres. Por el contrario, quienes expresan la diferencia de un modo

\footnotetext{
7 Excelente especialista de teoría literaria y de poesía latinoamericana, Reisz es creadora de conceptos como el de "voz sexuada", y suele defender con erudición posiciones poco frecuentes entre los investigadores, en las que reivindica el placer de la lectura frente a las exigencias de los dictámenes académicos.
} 
relativamente desnudo y directo no suelen tener buena acogida, ya que por lo general no se ve en sus textos la manifestación de una estética alternativa sino simple falta de calidad. (Reisz 2010: 80)

Lo cierto es que la presencia insidiosa del problema del valor de los textos, así como la visión ambigua acerca de la autoridad que tendrían las voces femeninas para hablar de temas universales desde un lugar propio, es decir, en tanto sujetos autónomos y en tanto autoras y no como meras "damas de letras" han permeado tanto la recepción crítica latinoamericana como la acción editorial en los años ochenta y noventa. Quizás podemos pensar que estamos ahora ante un momento diferente, en el que se afirma la presencia de nuevos actores del campo literario; un momento de transición, como lo sugiere Reisz, en el que se recogen, a pesar de todo, muchos resultados triunfales del reconocimiento de la creación femenina y de sus significados sociales. La revaloración de obras de escritoras de épocas pasadas (las viajeras románticas, las poetas y polígrafas del XIX, las poetas audaces del modernismo tardío, las artistas originales o moderadamente excéntricas del xx, las "diferentes" por su ascendencia, su sexualidad o su lengua) forma sin duda parte de esos triunfos bajo la forma de una justicia literaria rendida a obras y a protagonistas antes ocultadas, incomprendidas, menospreciadas. Pero la problemática del par hegemónico valor/autoridad puede seguir siendo observada hasta el fin del siglo xx también en combinación con otros parámetros usados negativamente, como la edad o la sexualidad, en una serie de casos que registran en sordina el rechazo o la indiferencia de la crítica (institucional o no, explícitamente evaluativa o no), de las editoriales y de los lectores.

Los ejemplos continentales pertinentes abundan en torno a la cuestión de la edad, la sexualidad o la identidad pública de las autoras, y se sitúan en particular en el paso de los ochenta a los noventa y aún después ${ }^{9}$. Me atendré a citar algunos casos argentinos. En materia de obstáculos editoriales: Matilde Sánchez (2011: 9) ha explicado qué difícil era para una escritora joven ser editada en los años en que propuso su primera y perfecta novela La ingratitud (concluida en 1986), retenida finalmente por Ada Korn para una tirada de mil ejemplares en 1992, y que luego quedó en el olvido hasta su reedición en 2011; Sylvia Molloy no logra publicar en Buenos Aires su primera novela En breve cárcel (1981), que narra una pasión lésbica, hasta 1998, diecisiete años después de haber sido editada en el extranjero (España); la obra más audaz de Elvira Orphée, La última

${ }^{8}$ Gloso el título irónico de la antología de narradoras compilada por María Moreno en 1998.

${ }^{9}$ En la literatura en lengua inglesa, un caso notable podría ilustrar esta zona de luchas que hoy parecen superadas, pero solo a costa de una intensa vigilancia que debería continuar siendo activa. Es el de Doris Lessing, eminente novelista que, superados los sesenta años, y después de haber publicado una buena docena de libros, decidió presentar a un editor dos novelas con forma de Diarios -los "Carnets" de Jane Somers: The Diary of a Good Neighbour y If the old could (1983) -, bajo nombre supuesto, haciéndose pasar por una autora joven y desconocida, a fin de testear tanto las barreras que se les ponen a las artistas noveles en razón de su anonimato, sexo y edad, como el grado de independencia de la crítica especializada. Su gesto provocador apuntaba riesgosamente a la puesta en cuestión de la "autoridad" del autor consagrado así como de los mecanismos que rigen la institución editorial. 
conquista del Ángel (1977), que contiene intensas escenas de tortura, no se publica nunca en Argentina sino en Venezuela, y no circula jamás en el mercado nacional; Cambio de armas (1982), de Luisa Valenzuela, que incluye una serie de cuentos donde la preocupación por el sexo se mezcla con las alusiones al abuso político y a la dominación, solo se edita en Buenos Aires en 2004, más de veinte años después de su aparición en los Estados Unidos. La lista de ejemplos podría, por cierto, alargarse bastante más ${ }^{10}$.

En cuanto al plano de la crítica, solo mencionaré aquí dos situaciones suficientemente explícitas. Por un lado, la cuestión de la revalorización de las obras: ciertas escritoras que hoy forman parte del canon argentino, como Silvina Ocampo, Norah Lange, o incluso Alejandra Pizarnik, llegan tardíamente a ocupar los lugares que les corresponden, en general hacia finales de los ochenta, y principalmente de la mano de otras autoras (Noemí Ulla, Sylvia Molloy), o de investigadores extranjeros (Daniel Balderston), o bien de grupos de acción feminista (el periódico Feminaria, por ejemplo, cuyo dossier Pizarnik data de 1996), y eso a pesar de la clarividencia de algunos críticos locales de excepcional sensibilidad, como Enrique Pezzoni, consejero de la casa Sudamericana y autor él mismo de ensayos sobre Ocampo y reseñas sobre Pizarnik. Por otro lado, la difusión de la palabra de las mujeres que escriben muestra cierta contracción en los libros de entrevistas de la misma época. El muy difundido en medios académicos Primera persona (1995), de Graciela Speranza, por ejemplo, solo incluye a tres escritoras sobre un total de quince autores. A su vez, el excelente volumen La curiosidad impertinente. Entrevistas a narradores argentinos (1993), del poeta y crítico Guillermo Saavedra, contiene dos diálogos con narradoras sobre un total de dieciocho entrevistas. Al menos en este caso, la inserción tiene el mérito de volver visibles a autoras poco conocidas hasta entonces (Ana Basualdo y Tununa Mercado).

Si en los ejemplos anteriores y en muchos otros semejantes se puede calibrar en definitiva la larga persistencia de los juicios de valor negativos sobre la creación femenina, o incluso las relaciones entre los aparatos de poder político y la opinión pública, que pueden imponer puntualmente sus marcas a la actividad editorial, es evidente que ellos sirven también para subrayar la historicidad del gusto y los límites de la crítica, tanto en su capacidad de comprender las variaciones de la forma y la aparición de nuevos imaginarios, como en su margen de acción concreta sobre el mercado de los lectores.

Actualmente, empero, se registran algunos cambios notorios en este panorama, debidos precisamente a la mundialización del saber y de la técnica, a la muchísima mayor difusión de publicaciones literarias de todo orden en la red, y a la presencia de textos en mercados y en sectores de consumo antes inexistentes

\footnotetext{
10 En el campo de la formación de cenáculos y la redacción de antologías, es útil recordar que ninguna mujer forma parte del grupo de escritores noveles "Shangai" y que todos los que "hacen" la revista Babel (1988-1991) son hombres (si bien luego escriben allí también algunas mujeres y María Moreno lleva incluso una columna de crónica). Varios años más tarde, una publicación bastante simbólica en su momento, como Buenos Aires. Una antología de narrativa argentina (Anagrama, 1992), de Juan Forn, uno de los emblemas de la promoción de escritores que eligió España como residencia y sede de publicación a principios de los noventa (junto con Rodrigo Fresán o Andrés Neumann), incluye entre los quince autores seleccionados únicamente a cuatro mujeres.
} 
o difícilmente alcanzables. Estos hechos bien conocidos, es decir, el paso de una sociedad de medios (tradicionales) de masas al mundo de lo virtual y lo digital, han transformado una buena parte de las leyes que regían la circulación del capital simbólico, y revertido la situación de algunas autoras al menos en lo que se refiere a la información sobre aquellas que han sido aceptadas por la crítica, o adoptadas por el público que se expresa en los blogs y por los medios especializados. A esta coyuntura se suma el nuevo contexto editorial en algunos países hispanoamericanos como la Argentina y en España misma, en el que florecen cantidad de pequeñas o medianas editoriales atentas a la promoción de talentos o incluso a la reedición de obras valiosas injustamente desatendidas u olvidadas. El caso de la argentina Pola Oloixarac y de su novela Las teorías salvajes (2008), por ejemplo, ilustra estos cambios, así como el desplazamiento geográfico del meridiano de la consagración, que parece pasar hoy por España, unido al gusto más reciente y glamuroso por las escritoras jóvenes y las obras irreverentes de un lado y otro del Atlántico. Después de una primera publicación en Argentina, recibida por opiniones muy favorables de escritores locales (Ricardo Piglia, Fogwill, Daniel Link), el gran espaldarazo al libro se lo dan, en efecto, la prensa y la edición españolas (una segunda edición salió en 2010 en Alpha Decay), que celebran unánimes la juventud y audacia de la autora, su actitud iconoclasta, su post-posmodernidad.

\section{Desafíos}

Ahora bien, un desafío inevitable se plantea cuando nos colocamos como observadores de la escritura femenina, evitando caer en posiciones esencialistas, y de frente a lo que aparece como un nuevo estadio en la historia cultural - Ilamémoslo globalización, mundialización, fin de milenio, época post-posmoderna, etc.-. Es la urgencia de describir de qué manera los textos construyen subjetividades diferentes y de detectar cuáles son los imaginarios actuales que definen las nuevas representaciones de los sujetos femeninos. Sujetos -autoras, personajes, voces narradoras- que parecen hoy día, dentro y fuera de la ficción, más libres de comenzar a "inventarse a sí mismos" (a sí mismas) (Castro Klarén 2003b: 35) e incluso de inducirnos a revisar "retazos específicos de los imaginarios nacionales" (Cárcamo Huechante y Fernández Bravo 2010: 23). Abordaré entonces aquí algunos ejemplos de literatura escrita por autoras argentinas que me parecen indicadores de esa transformación de las subjetividades escritas y trataré de determinar qué preocupaciones dibujan una línea común, característica de este momento de transición.

Mi punto de partida es la idea de que la narrativa de mujeres muestra en las últimas dos décadas una tendencia a aprovechar la libertad de expresión y de experiencia duramente conquistadas para diseñar una serie original de sujetos en proceso, capturados desde el inicio en la búsqueda y la conquista de posiciones afirmativas, pero también portadores de dudas sobre el origen, la lengua, la relación con la nación y la identidad del (de lo) extranjero. Es decir, de sujetos preocupados por la exploración de los lugares que han elegido (o que han recibido como destino) para decirse, más que por la construcción de identida- 
des resueltamente transgresivas. Es fácil observar que el discurso novelístico actual representa esos sujetos en construcción tanto en situaciones de desplazamiento y de contacto con el Otro como en situaciones de encierro y de denegación del exterior -coincida este con la ciudad, el país o el universo-, sin abandonar una tesitura investigadora, un pattern estilístico guiado por la encuesta que alguien efectúa sobre sí mismo (o sí misma) -y a veces, sobre el mundo-. A diferencia de muchas obras producidas en los setenta y los ochenta, en las que todavía dominaban los temas intimistas, sentimentales o de un ámbito afectivo y familiar tradicionalmente atribuido a las mujeres como su espacio social y textual "natural"11, a diferencia también de los textos producidos en moldes de literatura fantástica o enigmática, que les permitían tratar cuestiones difícilmente abordables en clave realista, desde la política hasta las sexualidades extravagantes o perversas ${ }^{12}$, a diferencia incluso de los ejercicios de la novela histórica o de aventuras con los que algunas escritoras mostraron su capacidad de competir con sus colegas hombres cultivando subgéneros apreciados por el público $^{13}$, estas obras del fin del milenio parecen esbozar preocupaciones que tienen que ver en primer término con la configuración de las identidades femeninas, pero alcanzan también a interrogar los límites de lo impersonal, de aquello que está más allá de marcos individualizados de género, de sexo o de pertenencia nacional. Se ponen así en escena nuevas sensibilidades, volcadas a delimitar atentamente los espacios desde los cuales ellas se autoenuncian, y nuevos tonos, donde ciertos tópicos clásicos como la memoria, la errancia o la creación artística misma se reinscriben con otros significados.

Observando los textos de las escritoras que analizaré y aun de otras para las cuales no habrá lugar suficiente aquí, diría que esos sujetos femeninos se encuentran representados en situaciones de desequilibrio y de salida de cauce (literalmente, de "desmadre"), pero no tanto de un desborde que equivaldría a un exceso gozoso, a una transgresión o a un corte absoluto, sino a un cruce de límites, acompañado o no de provocación, a una serie de circulaciones de ida y vuelta. En esos simbólicos levados de anclas las autoras vehiculan relatos de origen y fábulas de identidad de género, procesos de construcción personal, biográfica o seudobiográfica, autorreflexiva, muchas veces encarada bajo máscaras que permiten expresar aquella famosa "mirada femenina" tan debatida y a menudo combatida por la crítica. Durante esos trayectos las autoras, las narradoras y sus personajes rechazan la posición alterna, subalterna, sumergida o aun parasitada por voces complacientes con el mundo patriarcal (las voces ventrílocuas o travestidas), se despegan de los terrenos firmes de la identidad social y buscan

\footnotetext{
11 Los ejemplos abundan y hacen innecesaria la mención detallada, pero se puede en cambio recordar la primacía del cuento y el relato breve que desarrollan esos temas, así como el ejercicio de las memorias, los libros de recuerdos de infancia, etc.

12 En Argentina este registro va desde los cuentos de Silvina Ocampo escritos en los ochenta hasta las viñetas y relatos breves de Luisa Valenzuela, pasando por gran parte de la obra de Angélica Gorodischer y de la de Vlady Kociancich.

${ }^{13}$ Como lo hicieron por ejemplo Carmen Boullosa, Libertad Demitrópoulos, Rosario Ferré, Cristina Rivera Garza, Isabel Allende o Ángeles Mastretta.
} 
nuevas geografías imaginarias donde reinventarse. Por supuesto, estas escrituras nada tienen que ver con la literatura de viajes, ni con el exotismo o la crónica cosmopolita, ni con la búsqueda sistemática de nuevos patterns retóricos o de discursos insistentemente rupturistas. En realidad, las escritoras latinoamericanas han sabido a lo largo del tiempo incursionar en todos los modelos, y si hubo en el último tercio del siglo xx un terreno en el que asentaron su maestría técnica fue precisamente en el abordaje de todos o casi todos los géneros y subgéneros discursivos: baste pensar en obras que volumen tras volumen invisten modelos diversos, sin desdeñar incluso a veces un guiño hacia las teorías sociales, como las de Angélica Gorodischer, Cristina Rivera Garza, Griselda Gambaro, Luisa Valenzuela, Diamela Eltit, Carmen Boullosa... Pero ahora ya no aparece en primer plano la voluntad de mostrarse idóneas o rebeldes a través del manejo hábil de estéticas contrastadas o de la desviación paródica de las formas, sino el deseo de investigar un sentido diferente de la creación, entregándose a ese imaginario cortar amarras que trae la escritura ${ }^{14}$ en búsqueda de maneras renovadas de decir su autonomía subjetiva.

Varias soluciones narrativas recientes articulan esa problemática. Algunas novelas, como las que comentaré de Luisa Valenzuela, de Sylvia Molloy y de Matilde Sánchez ${ }^{15}$, lo hacen a partir de la construcción de subjetividades diaspóricas en las que coinciden por otra parte la experiencia viajera o exiliar de las autoras y donde se atisban indicios de autofiguración. Otras novelas, como la de Pola Oloixarac e incluso en parte la de la precitada M. Sánchez representan los lazos de la autoctonía para mejor poner en cuestión los orígenes. En cambio, una segunda línea articuladora -que dejaré para otra ocasión- se hace visible en obras que discuten con los archivos de la Historia a fin de proponer una restauración individual que supere la experiencia social. Es el caso de la novela de Liliana Heker El fin de la historia (1996), de algunos textos de Tununa Mercado, y parcialmente de la mencionada ficción de P. Oloixarac. También transforman el sentido de la experiencia personal libros de ensayo-ficción como Banco a la sombra (2007), de María Moreno, en los que se juega con los límites entre lo cronístico, lo ficticio y lo auto-figurativo ${ }^{16}$. Esta experiencia resulta doblemente interesante porque opera como impulso de transformación de la crónica, un género tradicionalmente ligado al realismo, a lo etnográfico y a la memoria cultural, al mismo

\footnotetext{
14 Autoras como Doris Lessing o Julia Kristeva, que han producido sus obras en el exilio, han hablado de la escritura como de una expatriación más radical que cualquier otra, y en el caso de Kristeva, incluso como de una forma de parricidio y matricidio simbólico de las mujeres. Alejandra Pizarnik, por su parte, escribió estos versos memorables: "explicar con palabras de este mundo / que partió de mí un barco llevándome" (Árbol de Diana).

15 Los textos seleccionados pertenecen a autoras argentinas; se entiende que el corpus queda abierto a escritoras de otras latitudes.

16 Las crónicas de M. Moreno, así como ella misma en sus declaraciones, entrevistas y páginas diversas, reivindican un corrimiento de los marcos discursivos del género cronístico y ofrecen una construcción original de la figura de la escritora, centrada en la idea de la libertad de invención y en la defensa de la autonomía de la creación escrita con respecto a jerarquías, a cánones y a la noción misma de obra. Sobre la vigencia de nuevas formas de la crónica, además de los artículos sobre la obra de María Moreno, se puede ver el breve ensayo de Aguirre (2012).
} 
tiempo que trabaja polémicamente el rechazo de ciertas formas de la autoridad social atribuida al escritor.

\section{Nomadías. Proximidades y distancias}

4.1. Como lo sostiene Leopoldo Brizuela, la obra de Luisa Valenzuela selecciona, contra la idea de literatura "correcta" y contra la aplicación inclemente de las normas de un género u otro, "la idea de escritura como travesía incesante en busca de una forma nueva", propone "una idea de escritor en permanente travesía por el mundo hacia lo desconocido y en constante diálogo con lo que acaba de conocer" (2003: 128).

Pero es necesario señalar igualmente que Valenzuela ${ }^{17}$ comparte con otras artistas latinoamericanas un papel protagónico en la emergencia de las nuevas corrientes de energía creadora que atraviesan las letras del continente a partir de los años ochenta, imponiendo relatos insólitos sobre la experiencia de las mujeres y testimoniando con desprejuicio sobre la realidad social. En ese periodo, esta escritora resulta también un caso relativamente excepcional por la audacia de muchas de sus ficciones y por su consecuente puesta en escena de la resistencia femenina al poder masculino. Así lo han reconocido una serie de lecturas que se pueden ordenar en una línea interpretativa sostenida, referida a menudo a su libro más traducido y comentado, Cambio de armas (2004 [1982]), aunque no exclusivamente a este ${ }^{18}$. De uno en otro de esos libros, en los pliegues de las referencias a la política, al autoritarismo, a la represión o a la voluntad de poder, se delinea con firmeza una conciencia de género opuesta a la pasividad y a los dictados ajenos, que intenta, muchas veces enmascarándose o travistiéndose, construir un camino propio:

Propongo también la escritura como máscara. ¿Qué máscara ponerse para empezar cada texto?, se preguntaba Italo Calvino en el momento de encarar "ese campo de fuerzas que es el campo narrativo", campo magnético en verdad que convierte en antena a quien escribe y atrae para sí las más inusitadas resonancias". (Valenzuela 2003: 80)

Varias novelas de Valenzuela donde esta búsqueda es explícita -desde Como en la guerra (1977) hasta Novela negra con argentinos (1990), La travesía (2001) y El Mañana (2010) - siguen un modelo de acciones basadas en la investigación sobre un secreto que tiene que ver con la sexualidad, una pesquisa que revela zonas profundas de las identidades femeninas. Poco a poco, el enfoque afirmativo de deseos sexuales y el de zonas fronterizas donde se ejerce la violencia de género, característico de las nouvelles de Cambio de armas, se va

\footnotetext{
17 La abundante obra de Valenzuela se desarrolla a lo largo de cuatro décadas y aborda varios géneros. Tiene ocho volúmenes de cuentos publicados y acaba de aparecer su décima novela, $L a$ máscara sarda (2012).

${ }^{18}$ Entre esos trabajos citaré a modo de ejemplo los de Lagos Pope (1987), Morello-Frosch (1990), Cordones-Cook (1991), Corbatta (1999), Medeiros-Lichem (2002), Franco (2003), Ramos Ortega (2010), Orecchia Havas (2013).
} 
transformando en un cuestionamiento sobre la dimensión cognitiva de la experiencia erótica. Estos temas suelen surgir también en ciertas narraciones en las que el onirismo se combina con recursos del relato fantástico o enigmático ${ }^{19}$ para colocarse en un borde en que lo político y lo sexual se deslizan hacia lo extraño o lo sobrenatural, vecino a ese género tan peculiar de cuentos con inflexiones visionarias que cultivó Cortázar. Pero lo característico de los textos de Valenzuela es que las mujeres que habitan sus historias se muestran siempre como las detentoras de un saber diferente, que parece residir en una oscura potencia de lenguaje, y que las hace blanco de ataques y persecuciones; son personajes que viajan hacia una subjetividad que hay que reconquistar o una sexualidad que hay que restaurar siguiendo un trazado de desvíos y movimientos vagabundos, de situaciones que dejan amplio margen a la ambigüedad y a la paradoja. De allí que esas narraciones se puedan leer, separándolas de las obras más directamente políticas de esta escritora o de las que trabajan sobre estereotipos culturales $\operatorname{argentinos}^{20}$, como capítulos de una suerte de épica femenina situada en un marco de deambulaciones urbanas cuyas heroínas retoman el paradigma de las mujeres rebeldes y curiosas que aparecen también en muchos de sus cuentos.

Las ficciones de esta serie, y en particular las dos últimas novelas, La Travesía y El Mañana, donde las protagonistas (respectivamente una antropóloga que debe rescatar unas viejas cartas eróticas y una escritora semi-incomunicada, mantenida en arresto domiciliario) están comprometidas en la recuperación de una parte esencial de su pasado, construyen sujetos femeninos que buscan reinventar su unidad perdida y elaborar y dominar la experiencia, es decir, adueñarse de su temporalidad personal desde una posición reafirmada de género ${ }^{21}$.

Gwendolyn Díaz pone precisamente de realce el sentido alegórico de la sucesión de los espacios y del nomadismo en El Mañana:

Laberintos, encarcelamientos, prisiones oscuras, espacios cibernéticos variados, barcos, basurales, espacios cultos de escritoras, espacios incultos (aunque sabios) de los cartoneros, pisos sin salida, sótanos oscuros, villas miseria, laberintos de cartón, bajos fondos urbanos, vericuetos escondidos... ¿Hacia dónde apunta todo eso, en el mundo valenzueliano, sino hacia una búsqueda, hacia la aventura del escritor que bucea desde su interior para lanzarse a escarbar en los basurales del inconsciente -como gatos eficaces- buscando encontrar el sentido, la palabra, la identidad del sujeto? (Díaz 2010)

Valenzuela sitúa sus ficciones en las ciudades que conoce mejor y en las que más ha vivido, Nueva York y Buenos Aires, o en sus zonas aledañas, escenografías urbanas que le permiten la reinscripción de ciertos motivos asociados

\footnotetext{
${ }^{19}$ Sobre la flexión onírica y fantástica de ciertos relatos de Valenzuela se pueden ver Filer (1995) y Bianchi (2011).

${ }^{20}$ Me refiero especialmente a Cola de lagartija (1983), Realidad nacional desde la cama (1990), La máscara sarda (2012).

${ }^{21}$ Dice el personaje de Elisa Algañaraz: "Y de eso se trata cuando se escribe de verdad, de trascender límites, de ir más allá de los miedos y de todo lo que una cree posible o imposible" (Valenzuela 2010: 51).
} 
a los umbrales de lo ilícito frecuentes en su obra, como el tópico de la atracción de los márgenes, o el de los tinglados ciudadanos del deterioro y del mal. Para sus personajes, caminar, trasladarse, ir y venir equivale siempre a avanzar, a autodeterminarse y a quebrar límites, aun cuando en esos quiebres de las fronteras físicas y simbólicas los aceche el riesgo del paso hacia la despersonalización y el anonimato o la fuga fuera de la propia temporalidad. En estas novelas $-\mathrm{y}$ en algunos de los cuentos de tema semejante, como "Tiempo de retorno" (2008)-, la figuración de las diásporas no excluye la de los regresos; al contrario, volver a Buenos Aires aparece como una etapa necesaria para recomponerse totalmente y quizás para volver a empezar nuevos exilios. Por eso algunas protagonistas como la del cuento mencionado emprenden el tramo final del camino descalzas, como si se tratara de una vuelta, temporaria pero también desnuda, a los orígenes. Así Valenzuela, viajera impenitente que ha vivido más de diez años en los Estados Unidos y en México, pero que retorna siempre a su casa porteña, ha cartografiado el territorio femenino recentrándolo en torno a las "citas a ciegas" (La Travesía) de las mujeres consigo mismas, que son investigaciones sobre sus deseos secretos, sus saberes prohibidos, su pasado enigmático.

La última novela citada aporta sin embargo una novedad en el orden de las tensiones heterotópicas. En El Mañana, la escritora, encerrada de fuerza en su casa, logra evadirse, y después de un descenso delirante hacia un estadio arcaico que representa su propia intemperie humana, alcanza un lugar de la ciudad donde reconstituir su yo y su lenguaje. Ese sitio es una villa miseria y evoca, con su paisaje de basura y precariedad, el mundo de los cartoneros, botelleros y piqueteros de la Argentina posterior al 2001, una Buenos Aires definitivamente empobrecida y "latinoamericanizada". El circuito de recuperación de la identidad pasa entonces esta vez por un paisaje de bajos fondos que ya no son peligrosos y novelescos como en las obras anteriores, sino hospitalarios y apegados a la realidad social. Es un deambular que no tiene finalidad etnológica (si hay un gesto realista en la descripción, este se mezcla siempre en los textos de esta autora con tonos alegóricos y simbólicos), pero que cruza umbrales para integrar la alteridad en lo propio, condición (ficcional) de la recuperación del lenguaje ${ }^{22}$.

4.2. Sylvia Molloy, ensayista y narradora de la misma generación que Valenzuela (ambas nacieron en 1938) -cuyos tonos y pattern estilístico difieren sin embargo considerablemente de los de esta-, trabaja también en su segunda ficción, El común olvido (2002), con un imaginario de las diásporas y con el autoexamen de sujetos que se construyen cruzando límites espaciales y lingüísticos. Molloy, autora de la así considerada primera novela de voz lesbiana de

\footnotetext{
22 Sin duda la obra narrativa que más se aproxima a la de Valenzuela en cuanto a la representación de nomadismos y diásporas de sujetos femeninos contemporáneos es la de Luisa Futoransky (1939), poeta y novelista argentina de la misma generación, igualmente frecuente viajera, pero afincada en París desde mediados de los ochenta. Sus novelas están en cambio recorridas por efectos humorísticos e irónicos mucho más acentuados que en los textos de Valenzuela, y ponen en escena un personaje femenino lúcido y perplejo cuyas aventuras y desventuras itinerantes remiten claramente a las de la autora. Ver Son cuentos chinos (1983), De Pe a Pa o de Pekín a París (1986), Urracas (1992).
} 
América latina, En breve cárcel (1983), pone en escena en El común olvido el cuestionamiento identitario del personaje de un argentino exiliado en los Estados Unidos, brevemente de retorno en Buenos Aires tras las huellas de un pasado evasivo o secreto que lo remite principalmente a su infancia y a su madre muerta.

Se trataría entonces de uno de aquellos relatos "del regreso", o aún mejor, del "afuera", en los que se entretejen el viaje y el descentramiento de los sujetos, y se especula sobre la extranjería, la ausencia, la pertenencia geográfica, cultural y lingüística. Memoriosas y cosmopolitas, tales narraciones son en efecto numerosas en el último cuarto de siglo de la literatura argentina. En general, proceden de artistas que viviendo o habiendo vivido fuera de su país, trazan caminos de ida y vuelta hacia él en textos con rasgos autoficcionales, o bien al contrario, alejan completamente el marco referencial situándolo en territorios lejanos o exóticos, o incluso "inventa[n] lo familiar desconfiando de las raíces" (Molloy 2006b: 20), pero trabajan, en todos los casos, con temáticas, posiciones subjetivas y marcas lingüísticas que apelan a la extraterritorialidad del escritor, real o imaginaria. Además de las obras de Luisa Valenzuela y de Luisa Futoransky, ya citadas, se pueden incluir en esa línea algunos libros de Alicia Borinsky, de Edgardo Cozarinsky, de Sergio Chejfec, de María Negroni, de Alberto Manguel, entre los que escriben en español y han residido o residen afuera, de Copi entre los que han escrito en otras lenguas.

Prefiero hablar de la escritura del afuera y no de la escritura del exilio porque la carga a menudo dramática de esta última palabra de algún modo oblitera la noción -engañosamente más simple- de desplazamiento. Si digo "afuera" presupongo un "adentro" al que, en teoría, puedo volver; si digo "exilio", la posibilidad de la vuelta es menos clara. Lo que me interesa principalmente es la escritura que resulta del traslado, la escritura como traslado, como traducción; la escritura desde un lugar que no es del todo propio y sin duda no lo será nunca, un lugar donde subsiste siempre un resto de extranjería y de extrañeza, donde se aprende a hablar una lengua nueva pero se escribe en la lengua que se trajo. (Molloy 2013)

Es indudable por otra parte que la extraterritorialidad no se mide simplemente en términos de lugar o de condiciones reales o ficticias de residencia del escritor, sino que está inscripta en la relación que sus textos mantienen con una ficción de origen y en la manera como actualizan una "poética de la distancia", es decir, una mirada crítica o reminiscente sobre la autoctonía.

El común olvido delimita esa mirada sobre el origen con una flexión discursiva de larga tradición rioplatense, el uso de la incertidumbre. Todas las pautas de la identidad personal del narrador aparecen entonces como parámetros poco o nada fiables, y el relato se centra en el equívoco protagonismo de la memoria, que actúa a partir de conjeturas y de paradojas, borrándose y reponiéndose a cada paso ${ }^{23}$. Así, aun cuando bajo la máscara de muchos personajes

\footnotetext{
23 Sobre la relación entre lenguaje y memoria en la novela, Laura Loustau dice: "En el afán por reconstruir un pasado, en las vivencias de las "sacudidas de la memoria" (El común olvido: 35 ) el lenguaje que se emplea se conecta a un vaivén entre desplazamiento y permanencia, entre
} 
se pueda identificar a varios miembros de la intelligentsia literaria de los años de juventud de la autora, y transluzcan entre otras dos afectuosas transposiciones en clave de las siluetas de José Bianco y de Enrique Pezzoni, el texto no propone la reconfiguración de una subjetividad a partir de la reconstitución de un paisaje social, como una suerte de relato de formación, sino un recorrido contradictorio que interroga las fronteras de la nación, de la ciudadanía, de la lengua, del sexo y del cuerpo.

La novela se abre con un retorno al lugar de origen (Buenos Aires) y se cierra sobre una nueva partida. Así se conjura el peligro que ronda al protagonista, la entrega a la fascinación del vacío o el abandono de sí que podrían llevarlo a quedarse varado en la ciudad natal. Los pliegues y las duplicaciones enigmáticas, las soluciones dobles abundan en su historia. Daniel posee dos (y casi tres) pasaportes, dos lenguas (y hasta tres, puesto que su inglés de argentino de ascendencia irlandesa educado en colegios británicos porteños es muy diferente del inglés que se habla en los Estados Unidos), una profesión (traductor) que se define por la circulación lingüística y cognitiva. Al volver por segunda vez a su lugar de origen siempre con un mismo propósito inconcluso, el traductor descubre la doble identidad sexual de su madre, pero pierde las cenizas de esta que debía dispersar, aunque termina echando en su lugar en el Río de la Plata otras que hacen perfectamente las veces de las primeras. Si el personaje alcanza finalmente el conocimiento de ciertos secretos y logra acercarse a algunos actores de su propio pasado e incluso confirmar recuerdos que de tan borrosos se han vuelto como intuiciones volcadas al futuro, su aventura parece destinada no a fragilizar sino a afirmar una subjetividad de entre dos mundos. Y lo que desaliena a ese sujeto es precisamente la no permanencia, el estar adentro y afuera de sus contextos de experiencia, el ser hablado en varios idiomas y en varios acentos, el transitar e irse, no el quedarse.

El común olvido, escrita en un estilo acompasado y preciso, que recuerda por momentos la elaborada tersura de los relatos de Bianco, hace ingresar en su textura lingüística los diferentes niveles y estilos del inglés y del español a los que alude, interviene en la lengua ideal de la nación desviándola con dialectos e idiomas que la enfatizan. Como su personaje, el texto absorbe esos lugares de lo marginal o de lo extranjero que son las hablas comunitarias, coloquiales, generacionales, pero tales incisos de oralidad no tienen carácter ilustrativo, más bien forman parte de la reflexión sobre una identidad que solo puede concebirse en términos de oxímoron, de autóctona extranjería. Extranjero es en la ficción también el que es diferente sexualmente (Daniel busca en viejos periódicos argentinos los nombres de la homosexualidad antes censurada en su propia lengua); exiliados (inmigrantes) y homosexuales serían las formas visibles de la disidencia argentina. Una subjetividad tal se fragua en el cuestionamiento constante de las fronteras, en el acercamiento de lo distante y en el desplazamiento de las cercanías. No es extraño entonces que los barrios de la capital se sucedan en el deambular del recién llegado como paisajes fantásticos donde se borra "cualquier sensación de límite" (Molloy 2011: 37); Buenos Aires se vuelve imprecisa como

destiempo y tiempo fijo, entre desorientación y orientación" (2006: 136). 
"una ciudad flotante que se va corriendo en otras direcciones, hasta que termine cayéndose en el Río de la Plata" (37), como una ciudad que estuviera "de paso" o que se sintiera lejana, como si se "la viera a distancia" (345); "La ventaja adicional del exilio", dice un personaje, "es que sales de un contexto sin entrar del todo en otro" (161). Un bello dato metaforiza esa apuesta textual tempranamente en el libro. Daniel, que luego tendrá el significativo oficio de traductor, no logra leer ningún libro en su totalidad, no puede entregarse a la literatura "por entero". El remedio que encuentra para esa carencia juvenil de la capacidad de "fijarse" sobre un mundo simbólico es traducir los fragmentos que lee. Sólo yendo y viniendo de un texto al otro, de una lengua a otra, de un imaginario a otro, puede "entender" y gozar lo que lee (34). Y luego, al anotar esas traducciones, conseguir la forma más vertiginosa de la aproximación al otro (a lo otro), su apropiación por la escritura. Como lo anota Jorge Panesi, en una aguda reseña del libro que insiste en la figura de la traducción como síntesis de lo que se traslada para que permanezca en otra memoria y en otra lengua:

Cercanía y distancia de la identidad. O cercanía y distancia de la traducción, doblez insuperable de la traducción: el narrador de Sylvia Molloy busca un pasado que le pertenece y le es ajeno. [...] Permanencia y traslado: en esta dualidad fundamental, imposible y sin embargo, necesaria, se juega toda la novela de Molloy. Y me atrevo a decir: toda identidad. (Panesi 2003: 25)

Es indudable que esta novela, tanto como En breve cárcel, podría leerse también como una obra programática por su cuidadosa selección de datos y de operaciones que señalan posiciones críticas militantes asumidas por la autora, tales como la necesidad de escribir desde un lugar desasosegado de diferencia sexual (Molloy 1998) ${ }^{24}$, o desde la descolocación lingüística (Molloy 2006b). O incluso por su voluntad explícita de contar a partir de la memoria invistiendo recuerdos propios y ajenos, para construir así una estética del fragmento donde desaparece la diferencia entre lo inventado, lo recordado, lo que se conjetura y lo verdaderamente ocurrido ${ }^{25}$. Esa lectura posible reforzaría la que acabo de esbozar, mostrando las relaciones estrechas entre la poética y la teoría y la persistencia en esta escritora de la preocupación por las estéticas extraterritoriales.

\section{TRASLACIONES, AUtOctonías, orígenes}

5.1. Si en El común olvido el cruce de los umbrales de la memoria se articula en torno a la figura de la madre, a las pesquisas ante testigos y actores del pasado y a las lecturas, en La ingratitud (1992, reeditada en 2011), de Matilde

\footnotetext{
24 En ese artículo Molloy interroga igualmente la noción de "extranjería" de un texto en los siguientes términos: "¿Qué significa escribir en (desde) otro lugar? ¿Cómo se tejen las sutiles relaciones entre autor, lengua, escritura y nación? ¿Cuándo empieza la extranjería de un texto? ¿En el desplazamiento geográfico, en el uso de otra lengua, en la extrañeza de la anécdota, en el efecto de traducción?" (1998: 30).

25 Sobre su reivindicada estética del fragmento y de la ruina, ver Speranza (1995: 133-145).
} 
Sánchez (1958), es la escritura, como práctica y como objeto, dirigida a un padre ficticio, lo que cristaliza los sentidos de la búsqueda subjetiva. Como lo indiqué antes, este es el primer libro de una autora celebrada sobre todo por sus novelas posteriores, El Dock (1993), finalista del premio Planeta, y El desperdicio (2007), y que publicó en Alfaguara su cuarta novela, Los daños materiales (2010). Como ocurre con algunas primeras obras, este relato impecable sobre la búsqueda empecinada de un lugar propio emprendida por una mujer (narradora y personaje en la ficción) que debe construir un yo autónomo desde el cual hablar y escribir, muestra una excepcional cristalización de la creatividad; la autora misma sugiere ese valor cuando afirma, en su prólogo a la reedición de La ingratitud, que "una novela de juventud, por breve que sea, es claramente un artefacto de pura invención como no se volverá a escribir nunca más" (2011: 10).

Una gran parte de la capacidad de fascinar al lector que el texto detenta viene de un recurso a una situación de pobreza originaria, de aislamiento, de penia filosófica, de rastreo por el incierto espacio del pensamiento en situación de encierro al cual acude la autora para diseñar a la protagonista. Discípula de Peter Handke, y aún más de Thomas Bernhard, Matilde Sánchez ha elegido enfrentar a su personaje con paisajes vaciados, donde la propia mirada es el único instrumento solitario que este posee para "montar" y comprender las escenas del día o los rigores de las estaciones, para definir el espacio y determinar el tiempo, para interrogar, enmarcadas por una ventana, las escenas callejeras repetidas donde se descompone el movimiento, se acelera o desacelera la marcha de los automóviles y donde la nieve cae sobre luces somnolientas. De Berlín, la ciudad donde se desarrolla la historia, se entrevén sobre todo monótonos paisajes invernales e inmigrantes -turcos, polacos, mexicanos, mujeres africanas- afectados por grados diversos de afantasmamiento, aunque no siempre de decadencia: los mexicanos, por ejemplo, medran invirtiendo astutamente el relato de sus fracasos personales y de las taras nacionales y convirtiéndolo en un cuento triunfal que les granjea las simpatías de todo el mundo, una solución existencial -"sepultar a su país"- que la ensimismada protagonista no puede evidentemente hacer suya. En una secuencia traída por el recuerdo, una estación balnearia argentina también invernal, evocada en contraste con la ciudad del presente, es el escenario que permite fijar el recuerdo del padre con la mayor incandescencia, contaminándolo de afecto y de ambivalencia (68-74).

El deambular de la protagonista anónima (tan anónima que cuando necesita fotografiarse el fotomatón quema la toma y le devuelve una figura de rostro blanco) por la ciudad en busca de gente conocida que pueda darle dinero, en busca de cabinas telefónicas desde donde llamar a un padre evanescente, de ida o de vuelta de excursiones urbanas con o sin propósito fijo, es evidentemente ajeno tanto a los ejercicios lúdicos de las mujeres de Luisa Valenzuela como a la voluntad arqueológica del personaje de Sylvia Molloy. Sobre todo, es ajeno a cualquier forma de celebración exotista, etnológica o cronística, y a las trivialidades de las imágenes del mundo global ${ }^{26}$. La narración le presta una mirada

26 Una lectura crítica de orientación post-colonial enfoca la novela a partir de la relación entre 
lúcida y distanciada, que registra un paisaje urbano en el que están tan afectados de extranjería los verdaderos extranjeros como los habitantes locales entregados a las delicias de las vidrieras abarrotadas de objetos de consumo, o como los marginales que comercian en plena luz del día con el trueque de documentos y de divisas. Se trata aquí de un Berlín (oeste) de antes de la caída del muro, de una ciudad que simbolizó como ninguna otra las fracturas del mundo moderno en el imaginario occidental, una ciudad de las fronteras, de los umbrales y de las falsas suturas. Y aunque el hilo menudo de la intriga propone a Berlín como un lugar ligado al pasado del padre y por lo tanto la justifica como un mirador imaginario hacia el hombre lejano, la ciudad se enuncia como un sitio de incertidumbre y de retiro en el que la narradora debe resolver su gran dilema: cómo contar de manera absolutamente autónoma, cómo escribir sin ceder a "los indicios reales". Ese espacio urbano inhóspito es un lugar de intemperie. Sin embargo, una vez más, la inclemencia no es solo exterior sino íntima (la muchacha "recoge" a un turco en su departamento, pero su mirada indiferente lo cosifica tanto como la vida alienada a la que el hombre se somete; ella misma recrea la ciudad palpablemente cercana como si fuera un objeto distante), y contradictoriamente, es el propio anonimato del personaje lo que resulta una garantía para la reconstrucción subjetiva. Como Berlín, la narradora tiene una herida que se abre recursivamente en el mismo sitio, quizás una metáfora de ese lazo filial del que manan angustia y desazón, y siente que solo su condición extra-territorial puede aliviarla:

Durante semanas enteras estuve mordiéndome el labio inferior con el colmillo siempre en el mismo punto. La pequeña herida original se extendió por el labio y acabó convirtiéndose en una úlcera blancuzca e inflamada. Pero esta tarde frente a la ventana sobre Hardenbergstrasse, que fluye como un río hacia el zoológico, me sentí liberada de todo propósito y ambición y advertí que el peso de mi anonimato en esta ciudad, mi situación impune, digamos, iba curándome. Y tuve la sensación excepcional de estar viviendo como yo quería. (Sánchez 2011: 50)

Son las fronteras lingüísticas las que mejor materializan ese mundo hecho de distancias y fisuras que las apariencias pueden hacer tomar erróneamente por una superficie lisa y continua, tal como el puente levadizo de Checkpoint Charlie o el tren que une los sectores este y oeste pueden dar la falsa impresión de que atraviesan un espacio libre y abierto. En la evocada incomprensión de sus lenguas respectivas por los inmigrantes y en el retrato de la inevitable torpeza de los que hablan la lengua de adopción (el alemán) como encerrados en una koiné prestigiosa pero impostada, están cifradas las preguntas que la novela plantea a un mundo de pactos sociales e internacionales dudosos, donde no queda más idea de patria que la que traducen los acentos siempre sofocados pero nunca perdidos de la lengua materna ${ }^{27}$.

exilio voluntario e identidad en el tiempo contemporáneo. Ver Graciela Ravetti (1999).

27 “Desde luego, jamás mencioné la profunda aprensión que me producía el solo hecho de oírlo hablar su idioma [alemán] correcto de academia y esos sonidos gangosos de los que no 
La representación de ese work in progress femenino en el camino de la doble construcción de una subjetividad y de una escritura pasa entonces en la novela por una quema de naves radical del personaje, que es el verdadero objetivo de su viaje ficticio, un despojarse de las imágenes, un entrar en el silencio, un concentrarse en un paisaje que "conserva su poder de desintegración" sobre ella, aceptando solo las figuras que surgen de las cosas mismas y no las que son producidas en series indiferenciadas por las máquinas y las técnicas (incluido el cine) de un mundo globalizado. Al final del recorrido la narradora conquista un centro, un punto axial por fin hallado para su historia personal, que le es revelado por un modesto cementerio situado del otro lado de la frontera, en la ciudad de Lützen (Alemania oriental), donde está la tumba de Nietszche. Ese viaje ficticio entre Berlín y Lützen es a la vez el más realista y el más alegórico de los desplazamientos que se mencionan en La ingratitud. Como ante el develamiento final de una clave, comprendemos que hemos leído una fábula en femenino sobre la(s) ruptura(s) necesaria(s) a la entrada en escritura, un relato mitopoético en el que se han figurado el arrancarse de las raíces, el estado de orfandad, el paso por la des-identificación, el dilema de la lengua, y el estado de regresión (de signo positivo) que preceden o acompañan el impulso creador ${ }^{28}$.

Por eso ese viaje reúne los hilos del tiempo, del espacio y de la personalidad en un único manojo. Abandonado el sustento obsesivo de la figura del padre, perdido todo verdadero legado, embebida en la nostalgia y quizás en el duelo, pero libre de toda angustia, la mujer que ha narrado su propia historia puede comenzar a ser libre (huérfana), a ser y a crear sin aferrarse a la seducción equívoca de una escritura destinada a halagar a su lector-como aquellas cartas al padre que buscaban divertirlo, entretenerlo, hablarle del mundo exterior-. El tramo final del periplo vuelve innecesario el regreso del personaje; geografías y temporalidades distintas se funden en una universal relativización del movimiento que, al revés de la solución de la novela de Molloy, no equivale a una opción por la im-permanencia sino a un desprendimiento y a un abordaje del deseo del límite, identificado ahora con la tensión creadora ${ }^{29}$. Es ese misterio lo que la luna de Lützen ilumina en la tumba de Nietszche.

podía desprenderse -ninguno de los innumerables turcos de esta ciudad ha conseguido nunca desprenderse de eso y alguien dijo que es en esos sonidos donde los turcos conservan su patria" (Sánchez 2011: 66).

28 Julia Kristeva ha teorizado y comentado en cantidad de trabajos la relación de la creación artística con el lazo de dependencia filial. Por ejemplo en los términos siguientes: [El imaginario de la obra opera una substitución de la dependencia entre la madre y el niño] "Sa substitution.. et son déplacement vers une limite fascinante parce qu'inhumaine. L'œuvre, c'est l'indépendance conquise à force d'inhumanité. L'œuvre coupe la filiation naturelle, elle est parricide et matricide, elle est superbement solitaire" (Kristeva 1985: 23).

${ }^{29}$ Un extenso artículo de Judith Filc (2004) estudia esta novela dentro de un corpus de obras de los noventa, producidas bajo el impacto del neo-liberalismo, que representan personajes que intentan infructuosamente apoderarse de un territorio personal. Tal lectura, sugestiva e informada, se ubica sin embargo en una perspectiva diferente que la que he intentado desarrollar aquí. La marginalidad de la protagonista es analizada por Filc como una forma de la autodestrucción y su aislamiento como una prueba de su fracaso en la construcción de un verdadero espacio íntimo donde se dé continuidad al pasado en el presente. 
5.2. En Las teorías salvajes (2008, reeditada en 2010 y 2011), primera novela de la escritora Pola Oloixarac (1977), la impulsión diaspórica aparece, en cambio, mediada por un dispositivo tecnológico, signo fiel de los tiempos. Se trata de una novela que tendría la tentación de llamar aquí "multimedia", porque reúne varios formatos que se alternan: un relato de culturas y tribus urbanas adolescentes, una novelita sentimental o de formación, un seudotratado antropológico, una narración de corte filosófico, todos investidos (pero unos más que otros) por un uso franco y a veces irresistible de la parodia y enmarcados en una peripecia que toma por escenario principal los claustros de la Facultad de Filosofía y Letras de Buenos Aires en la calle Puán, frecuentados tanto por la narradora como por la misma Oloixarac.

El amplio espectro de discursos narrativos que el libro contiene es centro de lecturas como la de Beatriz Sarlo, quien ve en la novela una suerte de "panegírico" contradictorio de la universidad que ficcionaliza hábilmente las heterotopías del saber porque en el fondo lo percibe como amenazado por el mundo actual. Sin embargo, la misma crítica advierte que la zona más creativa del texto se sitúa en otra parte:

En paralelo a la historia del desenfrenado erotismo filosófico de la narradora nacida y criada en Filosofía y Letras, hay otra historia, que transcurre en el escenario de lo semi fashion, semi cool, bizarro de Buenos Aires, donde cada minoría cultural es el centro de pequeños oleajes de celebridad marginal [...] Este abanico de life-styles tiene una dinámica merecidamente mayor que el reducto Puán de las pasiones filosóficas. (Sarlo 2012: 78-79)

Esos grupos juveniles, que protagonizan deambulaciones y transgresiones más o menos previsibles y animan las escenas de una microetnografía ciudadana, son precisamente los miembros de una generación que percibe la Historia como un dibujo animado obsoleto, y que solo se apasiona por los virtuosismos y la inteligencia de la red. Si la narradora en primera persona (esta forma se emplea en capítulos alternos y coopera en el guiño autoficcional que el personaje de la beIla y brillante estudiante de Filosofía lanza hacia la autora misma), absorbida por un deseo de probar la amplitud de su saber teórico y de su cultura humanista, puede aparecer como una figura reivindicatoria de la capacidad de erudición de las mujeres, los otros personajes viven sobre todo en el mundo de las imágenes virtuales y de la información instantánea. Esa pasión cataloga a los adolescentes nerds de la novela como hijos privilegiados de su época, a quienes el dominio de la cibernética, el mejor afrodisíaco contemporáneo, otorga el glamour que sus cuerpos inmaduros, torpes y feos no pueden asegurarles ${ }^{30}$.

Siguiendo este itinerario, Las teorías salvajes hace entonces otro uso a la vez novedoso y paródico (es decir, remisible a la tradición) de la cuestión de las

\footnotetext{
30 Hay que señalar también en su favor que las experimentaciones de los nerds de Oloixarac superan ampliamente en inventiva y conocimiento técnico a las de los hackers de Las islas (1998), de Carlos Gamerro, otra obra que enfoca (con objetivos diferentes) diversos grupos urbanos y la cultura under de la noche porteña, y que trabaja con los protocolos de los juegos electrónicos.
} 
heterotopías, que pone en relación con el placer sexual de los/las adolescentes y con su inocultable deseo destructivo, pero también con su creatividad delirante. Acudiendo al registro visual y a la descripción de cómo los personajes manipulan los simulacros, la novela potencia su enfoque de un presente auscultado a través de los hábitos, valores y experiencias de un grupo. Los chicos inventan en efecto una forma espectacular de distorsionar el espacio y el tiempo de su propia ciudad. Operando sobre los sistemas de traducción instantánea entre computadoras consiguen desviar todos los pedidos de información hacia su propio "envenenado" banco de datos, de manera que lo que salga de las máquinas porteñas pase inevitablemente por su propio servidor y produzca un resultado parasitado y falso, pero que parece verdadero ${ }^{31}$. El procedimiento, donde las imágenes auténticas son reemplazadas por otras arbitrarias, se llama "Pornografía del Espacio y Tiempo" (Oloixarac 2011: 234), y está acompañado por una serie de fotos de hecatombes y explosiones que transfiguran los sitios más simbólicos de la ciudad. La totalidad del dispositivo, a la vez una performance y una lectura de imágenes a la que se entregan tanto los adolescentes como la joven estudiante que ellos suelen confundir con "Pola", se revela en la escena final del libro en la que el mapa de la ciudad va cambiando junto con su historia en una exhibición a la vez simultánea y sucesiva, cronológica y acrónica, de los principales datos de la vida y la cultura de los argentinos, un poco como si los personajes de Oloixarac hubieran leído y quisieran ilustrar las ideas de Josefina Ludmer (2010) sobre el inevitable presente de la urbe globalizada, sobre el tiempo de la memoria reificado en lo actual y sobre la ciudad anacrónica y ucrónica del fin del milenio. En una respuesta alegremente paródica a la aventura de la casa de Carlos Argentino Daneri, la enumeración caótica de este aleph juvenil no revela por otra parte el universo, sino un solo centro desaforado, la irreemplazable Buenos Aires, que una antítesis definitiva califica con desparpajo: la ciudad parecía "un mamarracho", pero "lucía preciosa" (247) 32 .

Sin embargo, lo interesante de la solución distópica de Oloixarac es que el espacio y el tiempo así manipulados se abren hacia un curioso futuro epistemológico, ya que, como lo dice la ficción, cualquiera podría en adelante transformar digitalmente su lugar de origen, volviéndolo irreconocible. Un sueño de devastación se superpone entonces al esperable encomio del anonimato y lo supera. Se trata de metamorfosear el origen, pero también de entregarse a las delicias de su ruina y de su eventual desaparición, grado más alto de la realización utópica a la que tienden los descubrimientos cibernéticos de los nerds. De modo que aun cuando el mundo de Google nos haya franqueado el acceso al saber sobre cualquier punto del universo y de la cultura, y planteado una ilusoria cercanía de la realidad, la apuesta de la narradora y de los chicos porteños, que combaten

\footnotetext{
31 La explicación técnica a pie de página sobre la comunicación de las computadoras entre sí (Oloixarac 2011: 231), que aparece como una nota de "Q", el principal de los nerds, recuerda la inserción de notas pedagógicas (sobre psicoanálisis y sexualidad) que Puig introducía en El beso de la mujer araña (1976).

32 Un artículo reciente (De los Ríos 2014) pone énfasis en el cuestionamiento que la novela dirige a la tradición así como en la inserción narrativa de un archivo mediático.
} 
como el personaje de la joven Kamtchowsky ese "lugar inseguro y hostil" que les ha tocado en suerte en la tierra, requiere que todas las ciudades se valgan en el momento de hacer transitar la información ${ }^{33}$, para poder centrarse paradójicamente en el matricial "punto de origen" (249) a fin de volverlo indetectable. El resultado contradictorio del disparo hacia el horizonte visual y cibernético de las sensibilidades contemporáneas sería entonces ese deseo de desfiguración y anulación del origen, recorrido por la impulsión al anonimato. En esta propuesta me parece que se sitúa la zona más (filosóficamente) provocante y (políticamente) discutible de las pretendidas y satíricas "teorías salvajes".

\section{6. ÚLTIMOS PASOS}

Podríamos concluir observando que tanto en las novelas de Valenzuela citadas como en la de Molloy y en la de Matilde Sánchez se aborda la identidad desde la mirada femenina como una obra en constante ajuste y modificación, y se proponen procesos de subjetivación que hacen las cuentas con el pasado, con la lengua, e incluso con las figuras urticantes del padre o de la madre. El común olvido y La ingratitud explicitan, desde sus títulos mismos, el paso necesario (y culpabilizante, ingrato) del sujeto antes dependiente de los lazos de familia hacia su progresiva autonomía. Las dos novelas interrogan el sentido y las vías de la creación artística, así como, especialmente en el caso de la de Molloy, el problema de la transmisión. Pero el libro de Matilde Sánchez invoca también la cuestión de los orígenes como un tópico esencial al escritor (escritora) y elabora un imaginario de la construcción subjetiva a partir de la borradura de todo lo previo y de una desnudez existencial absoluta. En Las teorías salvajes en cambio, se puede encontrar una suerte de imagen en anamorfosis, un tanto desfigurada y abarrotada, de una preocupación semejante, que ahora podría enunciarse con la urgencia de una pregunta del fin de los tiempos: ¿qué hacer con el lugar de origen?, ¿cómo investirlo y procesarlo de manera radical? En la más nueva de las escritoras aquí reunidas la solución es entonces, por el momento, veloz y polémica: solo reduciéndolo a cenizas o volviéndolo totalmente otro, ese lugar puede aún ser hablado por la literatura.

\section{OBRAS CITADAS}

Aguirre, Osvaldo (2012): "A la deriva". En: Cuadernos Hispanoamericanos, n. ${ }^{\circ} 744$, pp. 9-12. Bianchi, Sandra (2011): "Abierta al misterio: la 201 de Luisa Valenzuela". En: Cuadernos del CILHA, vol. 12, n. ${ }^{\circ}$ 2. Disponible en <http://www.scielo.org.ar/scielo.php?script=sci_ arttext\&pid=S1852->. Última visita: 24.10 .2012

\footnotetext{
${ }^{33}$ La pérdida del aura prestigiosa o exótica de que estaban investidas las ciudades extranjeras está presente en buena parte de la literatura latinoamericana actual. En términos exasperados, que satirizan la muerte del deseo que caracteriza a la mirada turística y la ausencia de sentido de los desplazamientos espaciales, se la puede leer en cuentos como "Viajando se conoce gente", de Ana María Shua (Como una buena madre, 2001).
} 
Brizuela, Leopoldo (2003): "Las dos travesías de Luisa Valenzuela". En: Luisa Valenzuela: Escritura y Secreto. Madrid, Fondo de Cultura Económica de España, pp. 123-144.

Butler, Judith (2005): Trouble dans le genre. Pour un féminisme de la subversion. París, La Découverte.

Castro-Klarén, Sara (ed.) (2003a): Narrativa Femenina en América Latina. Prácticas y perspectivas teóricas. Madrid/Frankfurt, Iberoamericana/ Vervuert.

(2003b): "Introduction: Feminism and Women's narrative: thinking common limits/ links". En: Sara Castro-Klarén (ed.): Narrativa Femenina en América Latina. Prácticas y perspectivas teóricas. Madrid/Frankfurt, Iberoamericana/Vervuert, pp. 9-38.

Cárcamo-Huechante, Luis E., y Fernández Bravo, Álvaro (2010): "Introducción. Revisiones críticas: Independencias, Centenarios y Bicentenarios". En: Revista de Crítica Literaria Latinoamericana, vol. xxxvı, n. ${ }^{\circ} 71$, pp. 11-26.

Corbatta, Jorgelina (1999): "Narrativas de la Guerra Sucia: Luisa Valenzuela". En: Narrativas de la Guerra Sucia en Argentina. Buenos Aires, Corregidor, pp. 101-117.

Cordones-Cook, Juanamaría (1991): Poética de la transgresión en la novelística de Luisa Valenzuela. Nueva York, Peter Lang.

De los Ríos, Valeria (2014): "Mapa cognitivo, memoria (im)política y medialidad: contemporaneidad en Alejandro Zambra y Pola Oloixarac". En: Revista de Estudios Hispánicos, vol. XLVIII, n. ${ }^{\circ} 1$, pp. 145-160.

Díaz, Gwendolyn (2010): "Espacios interiores y exteriores en El Mañana de Luisa Valenzuela". En: <http://www.luisavalenzuela.com/el_manana_gwendolyn_diaz.html>. Última visita: 24.10 .2012 .

Drucaroff, Elsa (2011): Los prisioneros de la torre. Política, relatos y jóvenes en la postdictadura. Buenos Aires, Emecé.

Filc, Judith (2004): "Desafiliación, extranjería y relato biográfico en la novela de la posdictadura". En: Ana Amado y Nora Domínguez (comps.): Lazos de familia. Herencias, cuerpos, ficciones. Buenos Aires, Paidós, pp. 197-229.

Filer, Malva (1995): "Las transformaciones del cuento fantástico en la narrativa rioplatense (1973-1993): Luisa Valenzuela y Mario Levrero". En: Roland Spiller (ed.): Culturas del Río de la Plata (1973-1995). Transgresión e intercambio. Frankfurt am Main, Vervuert, pp. 531-543.

Franco, Jean (2003): “¿Es la tortura materia literaria?". En: Decadencia y caída de la ciudad letrada. Barcelona, Debate, pp. 316-317.

Futoransky, Luisa (1986): De Pe a Pa o de Pekín a París. Barcelona, Anagrama. (1991): Son cuentos chinos. Buenos Aires, Planeta. (1992): Urracas. Buenos Aires, Planeta.

Gamerro, Carlos (2011): Las islas. Buenos Aires, Norma.

Genovese, Alicia (1998): La doble voz. Poetas argentinas contemporáneas. Buenos Aires, Biblos.

Gramuglio, María Teresa (2012): "Los deseos renovados del americanismo". En: Cuadernos Hispanoamericanos, n. ${ }^{\circ} 743$, pp. 59-68.

Gutiérrez-Mouat, Ricardo (2010): "Cosmopolitismo y latinoamericanismo: nuevas propuestas para los estudios literarios". En: Julio Ortega (ed.): Nuevos hispanismos interdisciplinarios y transatlánticos. Madrid/Frankfurt, Iberoamericana/Vervuert, pp. 103-128. 
Kristeva, Julia (1985): "Entretien avec Julia Kristeva". En: L'indépendance amoureuse. Les Cahiers du GRIF, n. ${ }^{\circ} 32$, pp. 7-23.

Lagos Pope, María Inés (1987): "Mujer y política en Cambio de armas de Luisa Valenzuela". En: Hispamérica, n. ${ }^{\circ} 46-47$, pp. 71-83.

Lessing, Doris (1995): Dans ma peau. Autobiographie 1919-1949. París, Albin Michel.

(1998): La marche dans l'ombre. Autobiographie 1949-1962. París, Albin Michel.

Loustau, Laura R. (2006): "Memoria y lenguaje en El común olvido y Varia Imaginación de Sylvia Molloy". En: Anclajes, vol. X, n. ${ }^{\circ}$ 10, pp. 127-139.

Ludmer, Josefina (2010): Aquí América latina. Una especulación. Buenos Aires, Eterna Cadencia.

Medeiros-Lichen, María Teresa (2002): Reading the Feminine Voice in Latin American Women's Fiction. From Teresa de la Parra to Elena Poniatowska and Luisa Valenzuela. Nueva York, Peter Lang.

Moi, Toril (2009): "'I am not a woman writer'. About women, literature and feminist theory today". En: Samtiden, n. ${ }^{\circ}$ 3, 2008. Reproducido en Eurozine, 12.06 .2009 (<http:// www.eurozine.com/articles/2009-06-12-moi-en.html>). Última visita: 31.03.2013.

Molloy, Sylvia (1998): "En breve cárcel: pensar otra novela". En: Punto de Vista, n. ${ }^{\circ} 62$, pp. 29-32.

(2006a): "Identidades textuales femeninas: estrategias de autofiguración". En: Mora, n. ${ }^{\circ} 12$, pp. $68-86$.

(2006b): "A modo de introducción. Back home: un posible comienzo". En: Sylvia Molloy y Mariano Siskind, (eds.): Poéticas de la distancia. Adentro y afuera de la literatura argentina. Buenos Aires, Norma, pp. 15-21.

- (2011): El común olvido. Buenos Aires, Eterna Cadencia.

- (2013): "Literatura, una patria sin fronteras". En: ADN Cultura. La Nación, 20 de septiembre.

Molloy, Sylvia, y Siskind, Mariano (eds.) (2006): Poéticas de la distancia. Adentro y afuera de la literatura argentina. Buenos Aires, Norma.

Morello-Frosch, Marta (1990): "Discurso erótico y escritura femenina". En: Coloquio Internacional. Escritura y sexualidad en la literatura hispanoamericana. Madrid, Centre de Recherches Latino-Américaines Université de Poitiers / Editorial Fundamentos, pp. 21-30.

Moreno, María (2007): Banco a la sombra. Buenos Aires, Sudamericana.

Oloixarac, Pola (2011): Las teorías salvajes. Buenos Aires, Entropía.

Orecchia Havas, Teresa (2012): "Trois lectures du corps en mouvement". En: Milagros Ezquerro y Nadia Mékouar-Hertzberg (dirs.): Rencontres avec Gradiva. Hommage a Michèle Ramond. París, Indigo, pp. 358-375.

Ortega, Julio (ed.) (2010): Nuevos hispanismos interdisciplinarios y transatlánticos. Madrid/ Frankfurt, Iberoamericana/Vervuert.

Panesi, Jorge (2003): "Presentación de El común olvido". En: Nueve Perros, vol. 2, n. ${ }^{\circ} 2 / 3$, p. 25.

Ramond, Michèle (2011): Quant au féminin. Le féminin comme machine à penser. París, L'Harmattan.

Ramos Ortega, Belén (2010): "La escritura con el cuerpo o el cuerpo de la escritura: aproximación a una poética de la subversión en Luisa Valenzuela". En: Espéculo.

430 | Pasavento. Revista de Estudios Hispánicos, vol. II, n. ${ }^{2} 2$ (verano 2014), pp. 407-431, ISSN: 2255-4505 
Revista de estudios literarios, n. ${ }^{\circ}$ 44. Disponible en <http://www.ucm.es/info/ especulo/numero44/escuerpo.html>. Última visita: 24.10. 2012.

Ravetti, Graciela (1999): "La ingratitud, de Matilde Sánchez: representaciones del exilio". En: CALIGRAMA. Revista de estudios románicos, n. ${ }^{\circ}$ 4, pp. 41-52.

Reisz, Susana (1996): Voces sexuadas. Género y poesía en Hispanoamérica. Lérida, Ediciones de la Universitat de Lleida.

- (2010): "¿El premio será otra carrera? (El lugar de la mujer escritora en el hispanismo del futuro)". En: Julio Ortega (ed.): Nuevos hispanismos interdisciplinarios y transatlánticos. Madrid/Frankfurt, Iberoamericana/Vervuert, pp. 77-101.

Sánchez, Matilde (2011): La ingratitud. Buenos Aires, Mardulce.

Sarlo, Beatriz (2012): "La teoría en tiempos de Google". En: Ficciones argentinas. Buenos Aires, Mardulce, pp. 75-79.

Shua, Ana María (2001): Como una buena madre. Buenos Aires, Sudamericana.

Speranza, Graciela (1995): Primera persona. Conversaciones con quince narradores argentinos. Buenos Aires, Norma.

Steiner, George (1997): "Lire en frontalier". En: Passions impunies. París, Gallimard, pp. 119142.

Valenzuela, Luisa (2003): Escritura y Secreto. Madrid, Fondo de Cultura Económica de España.

- (2007): La Travesía. Barcelona, Belacqua.

- (2010): El Mañana. México, Fondo de Cultura Económica.

VV.AA. (2009): "Sección monográfica: literatura y globalización en América latina". En: Revista de Crítica. Literaria Latinoamericana, vol. xxxv, n. ${ }^{\circ} 69$. 